\title{
AEDES AEGYPTI SURVIVORSHIP ON SALT TOLERANT CALIFORNIA LANDSCAPE PLANTS
}

\author{
CHRISTOPHER S. BIBBS', JESSE E. CROSIER ${ }^{1,2}$, RUI-DE XUE', \\ GUNTER C. MÜLLER ${ }^{3,4}$, AND WHITNEY A. QUALLS 5,6 \\ 'Anastasia Mosquito Control District, 120 EOC Drive, St. Augustine, FL 32092 \\ ${ }^{2}$ Current address: St. Johns County Department of Health, \\ 200 San Sebastian View, St. Augustine, FL 32084 \\ ${ }^{3}$ Malaria Research and Training Center, Faculty of Medicine, Pharmacy and \\ Odonto-Stomatology, University of Bamako, BP 1805, Bamako, Mali \\ ${ }^{4}$ Department of Microbiology and Molecular Genetics, \\ IMRIC, Kuvin Centre for the Study of Infectious and Tropical Diseases, \\ Faculty of Medicine, Hebrew University, Jerusalem 91120, Israel
}
${ }^{5}$ University of Miami, Miller School of Medicine, 1600 Northwest $10^{\text {th }}$ Avenue \#1140, Miami, FL 33136

\begin{abstract}
${ }^{6}$ Current address: Texas Department of State Health Services, Arbovirus and Entomology, 1100 West $49^{\text {th }}$ Street, Austin, TX 78714
\end{abstract}

Guest Editor: M. Miah

\begin{abstract}
Aedes aegypti has expanded its range in the United States to include various arid and desert geographies, with notable introduction into various parts of California. Because resources are limited in arid environments, it is currently an important topic to understand how $A e$. aegypti interacts with its surrounding environment for survival and proliferation. Three common plant species in peridomestic landscape, i.e., salt cedar (Tamarix aphylla), arrow weed (Pluchea sericea) and four wing saltbush (Atriplex canescens), were collected for survival bioassays to understand how Ae. aegypti is persisting in arid, chaparral landscapes in California, USA. These three plant-species along with a $10 \%$ sucrose solution (positive control) and reverse osmosis water solution (negative control-) were added to cages of $A e$. aegypti to assess their survival at $24 \mathrm{~h}, 48 \mathrm{~h}$, and $96 \mathrm{~h}$. It was found, in comparison with the negative control and four wing salt bush, that arrow weed and to a lesser extent salt cedar, promoted survival of Ae. aegypti in the first 24h. After the first day, only arrow weed significantly supported mosquito survival out to $96 \mathrm{~h}$ as compared to the controls. Arrow weed and salt cedar are both riparian plants producing some nectaries which could be energy resources provided through stem sap or nectar to Ae. aegypti amidst peridomestic chaparral in California.
\end{abstract}

Key Words: Aedes aegypti, survivorship, Pluchea sericea, Tamarix aphylla, Atriplex canescens

\section{INTRODUCTION}

Aedes aegypti (L.) is a potential vector for several globally significant emergent and re-emergent viral pathogens (Paules and Fauci 2017). In recent years, intermittent introductions of $A e$. aegypti L. into the arid southwest (Madon et al. 2002) eventually resulted in breeding populations in the desert chaparral of California, USA (GloriaSoria et al. 2014; Henke 2016). Arid lands are not inherently considered ideal habitats for Ae. aegypti, but their ecology, as with other mosquitoes, is intrinsically dependent on the availability of plants as an oasis of resources. Particularly, the need to feed on sugar is limiting for both male and female mosquitoes (Yuval 1992). Hence, the 
survivorship of Ae. aegypti regarding the viability of chaparral plants in peridomestic environments is the primary interest of this study.

Preliminary land cover analysis was performed by surveying peridomestic chaparral in Coachella Valley for common plants associated with urban landscapes. It was found that three plant species like salt cedar (Tamarix aphylla), arrow weed (Pluchea sericea) and four wing saltbush (Atriplex canescens) were most common in that area.

Studies in arid and ecologically transitional environments have shown mosquitoes can acquire sugar from flowers, extra-floral nectars, honeydew, fruits, and by directly piercing soft plant tissues to extract sap (Yuval 1992; Müller et al. 2010; 2011). Additionally, the arid tree Tamarix jordanis is favored by Culex pipens L. for sugar feeding (Schlein et al. 2008). It stands that salt cedar, arrow weed, and four wing saltbush may provide amenable sugar resources for the survival of Ae. aegypti in an otherwise resource deprived environment. In the present study, therefore, survival bioassays were conducted with some plant species to investigate the impact of these plants on survivorship of invasive $A e$. $a e g y p t i$, and also to determine the possibility of Ae. aegypti forage on these plant species for survival.

\section{MATERIALS AND METHODS}

Aedes aegypti mosquitoes were collected from the United States Department of Agriculture, Agricultural Research Service, Center for Medical, Agricultural, and Veterinary Entomology and reared in insectaries maintained at $26.6^{\circ} \pm 1^{\circ} \mathrm{C}, 80 \pm 0.5 \%$ relative humidity, and a $14 \mathrm{~L}: 10 \mathrm{D}$ photoperiod. Survival bioassays were conducted with 20 adult females of $A e$. aegypti (5-7d and nonblood fed) that were sugar-starved for $24 \mathrm{~h}$ prior to the experiments. The tested plant species i.e. salt cedar, arrow weed, and four wing saltbush were collected from native peridomestic landscapes in Indio, CA, USA. The cuttings from these plants were stored in $900 \mathrm{ml}$ of reverse osmosis (RO) water in a glass bottle for testing.
The general bioassay design required modifying a 5-gallon bucket by cutting open a $30 \mathrm{~cm} \times 30 \mathrm{~cm}$ opening in the face and securing a $60 \mathrm{~cm}$ length of cylindrical stockinet to the opening as an entry tunnel. The top of the bucket was enclosed with $2 \mathrm{~mm}$ hardware cloth mesh (Fig. 1). A set of three plant cuttings of the same plant for a given species were admitted to the bucket and a batch of 20-mosquitos was aspirated into the cage. After securing the cage by tying off the stockinet and housing the cages were placed in insectary rearing conditions, bioassays were conducted for 96h. Each plant was evaluated three times in four replicates per evaluation period. For each replicate, there was a positive control and a negative control. The positive control consisted of cotton balls soaked with $10 \%$ sucrose solution and the negative control consisted of cotton balls soaked in RO water. Once bioassays started, Ae. aegypti survival was documented at $24 \mathrm{~h}, 48 \mathrm{~h}$, and $96 \mathrm{~h}$ for each treatment and control. Survivorship at each time of observation was averaged across replicates but

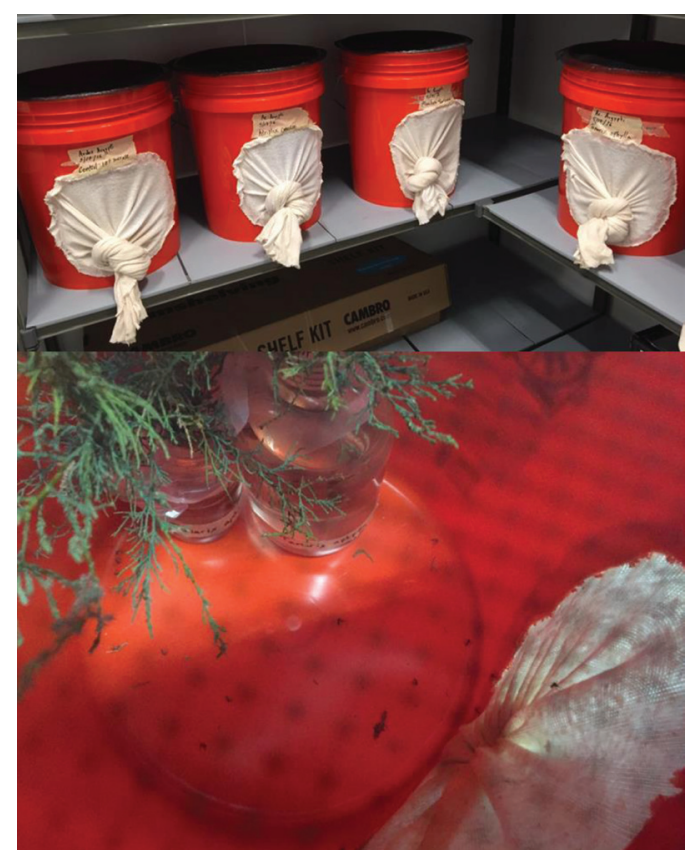

Figure 1. Bucket cage design. Top: A 5-gallon bucket with $30 \times 30 \mathrm{~cm}$ front panel removed. The front face was enclosed by securing a $60 \mathrm{~cm}$ length of cylindrical stockinet. Bottom: Salt cedar cuttings nested in water for conducting a bioassay. 
within respective treatments and analyzed using repeated measures ANOVA and post hoc paired t-tests.

\section{RESULTS AND DISCUSSION}

The mean percentage Ae. aegypti survival at $24 \mathrm{~h}, 48 \mathrm{~h}$, and $96 \mathrm{~h}$ during exposure to treatments and control are summarized and presented in Figure 2. Ae. aegypti survived to a significantly greater degree on arrow weed and salt cedar at $24 \mathrm{~h}$, compared to the negative control $(F=14.3, \mathrm{df}=4, p<0.0014)$. At $48 \mathrm{~h}$, significantly more survival was observed in arrow weed than negative controls $(F=6.60, \mathrm{df}=$ $4, p<0.0148)$, with salt cedar no longer having significantly different survival than the negative control. At $96 \mathrm{~h}$, arrow weed remained the only treatment group to have significant survival, as compared to negative controls $(F=$ $2.82, \mathrm{df}=4, p<0.0307)$. A significant proportion of Ae. aegypti were not observed to survive on four wing saltbush at any observation time.

Arrow weed, and to a lesser extent salt cedar, allowed $A e$. aegypti to survive significantly more in the first $24 \mathrm{~h}$ of the bioassay than being without sugar resources. However, arrow weed was the only significant treatment after the first $24 \mathrm{~h}$. The plant was not openly flowering and no direct observations could be identify the feeding/probing site during the bioassay. Arrow weed appeared to be a moderately fleshy, soft tissue plant on both stems and leaves. It is possible that Ae. aegypti enhanced survival is an example of their ability to draw nutrients directly from the plant vegetative structures. Salt cedar had small florets adorning the terminal ends of the cuttings, which may explain the increased survivorship on salt cedar for the first $24 \mathrm{~h}$. Given the arid landscape nature of the plants, it is possible the holding conditions were detrimental to the salt cedar, which may have reduced the viability of the flowers past the first 24 hours. This plant was also the only one in a tree growth form. In contrast, four wing saltbush, was similarly fleshy and green as in the case of arrow weed. The plant was somewhat woodier than arrow weed, so it is possible that there is something similar between salt cedar and four wing saltbush that prevented them from being viable to the survivorship of Ae. aegypti for the duration of the bioassay.

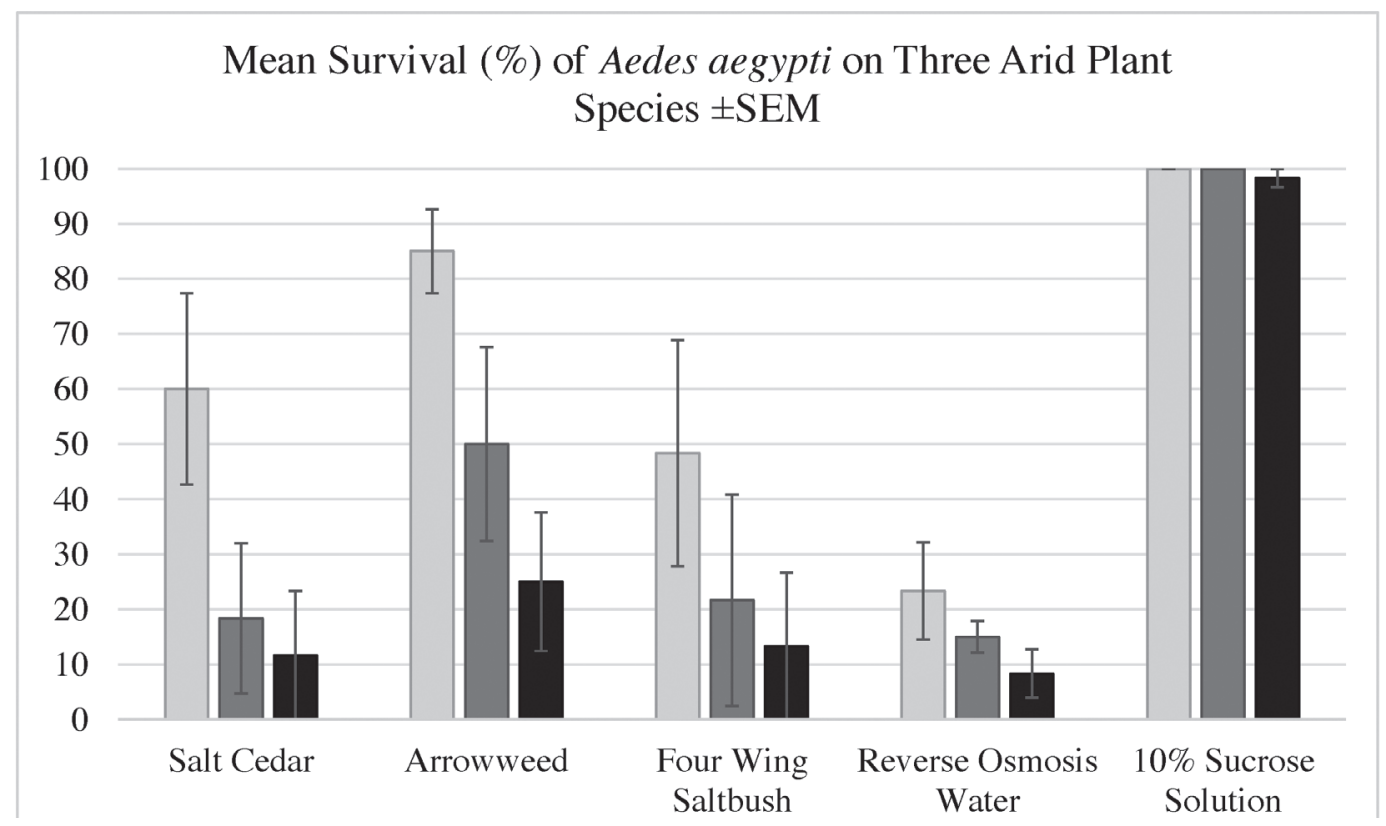

Figure 2. Cluster bar graph showing the mean percent survival of adult female Aedes aegypti (L.) when exposed to salt cedar (Tamarix aphylla), arrow weed (Pluchea sericea) and saltbush (Atriplex canescens); a reverse osmosis water (negative control); and a 10\% sucrose solution (positive control). Values are displayed with standard error of the mean as I-bars. 
With that context, the utility of arrow weed as a harborage or sugar resource may be contingent on the associated sub-populations of Ae. aegypti having heat, salt, or xeric tolerance. Population genetics has now incriminated Ae. aegypti in multiple introductions into California (Pless et al. 2017). These introductions are thought to have stemmed from south-central and south-western desert populations of Ae. aegypti in North America (Pless et al. 2017), and reflect that the established breeding populations of this mosquito species in southern California may already have been selected for fitness in arid lands. Additionally, all three plant species have differentiating qualities that may prove harsh for mosquitoes. Four wing saltbush is alkaline, having various medicinal uses for native desert tribes (Camazine and Bye 1980) that may in turn indicate it is unappealing or toxic to Ae. aegypti. In contrast, salt cedar is highly resistant to salt and alkaline conditions and develops in riparian areas (Griffin et al. 1989), possibly indicating this as a microhabitat suitable for Ae. aegypti. Arrow weed is also a salt tolerant riparian plant in coastal scrublands in the southern coastal basin of California (Boufford 1997), and may be the best indicator of potential for Ae. aegypti to harbor and survive. Regardless of habitat indication, $A e$. aegypti can survive for several days with only arrow weed as a sugar resource, implying a relationship in arid lands that may account for how Ae. aegypti survives in peridomestic chaparral in California, and this information may benefit for managing Ae. aegypti in arid lands.

\section{ACKNOWLEDGEMENTS}

This research was funded by the Coachella Valley Mosquito and Vector Control Dis- trict. Technical guidance and support was provided by Gregory White and Jennifer Gibson-Corrado.

\section{REFERENCES CITED}

Boufford DE. 1997. Asteraceae - Pluchea. In: Flora of North America Editorial Committee, eds. Flora of North America North of Mexico. Vol. 19, pp. 3-70. Oxford University Press, Oxford, UK.

Camazine S, Bye RA. 1980. A study of the medical ethnobotany of the Zuni Indians of New Mexico. JEthnopharmacology 2: 365-388.

Glorida-Soria A, Brown JE, Kramer V, Yoshimizu MH, Powell JR. 2014. Origin of the dengue fever mosquito, Aedes aegypti, in California. PLoS Negl Trop Dis 8: e3029.

Griffin GF, Smith DM, Morton SR, Allan GE, Masters KA, Preece N. 1989. Status and implications of the invasion of tamarisk (Tamarix aphylla) on the Finke River, Northern Territory, Australia. JEnviron Manag 29: 297-315.

Henke, JA. 2016. Fighting Aedes aegypti in the California desert, Wing Beats 27:23-27.

Madon MB, Mulla MS, Shaw MW, Kluh S, Hazelrigg JE. 2002. Aedes albopictus (Skuse) introduction into southern California and potential for its establishment. J Vect Ecol 27: 149-154

Müller GC, Xue RD, Schlein Y. 2010. Seed pods of the carob tree Ceratonia siliqua are a favored sugar source for the mosquito Aedes albopictus in coastal Israel. Acta Trop 116: 235-239

Müller GC, Xue RD, Schlein Y. 2011. Differential attraction of Aedes albopictus in the field to flowers, fruits, and honeydew. Acta Trop 118:45-49

Paules CI, Fauci AS. 2017. Yellow fever - Once again on the radar screen in the Americas. N Engl J Med 376: 1397-1399.

Pless E, Gloria-Soria A, Evans BR, Krame V, Bolling BG, Tabachnick WJ, Powell JR. 2017. Multiple introductions of the dengue vector, Aedes aegypti, into California. PLoS Negl Trop Dis 11: e0005718.

Seeger KE, Scott JM, Muller GC, Qualls WA, Xue RD. 2017. Effect of common species of Florida landscaping plants on the efficacy of attractive toxic sugar baits against Aedes albopictus. J Am Mosq Control Assoc. 33:139-141.

Schlein Y, Müller GC. 2008. An approach to mosquito control: using the dominant attraction of flowering Tamarix jordanis trees against Culex pipiens. J Med Entomol 45: 384-390

Yuval B. 1992. The other habit: sugar-feeding by mosquitoes. Bull Soc Vector Ecol, 17: 150-156. 